\section{GENETICS FOR BEGINNERS}

\section{An Introduction to Genetics}

By Dr. C. M. M. Begg. (Biological Science Texts.) Pp: $x i+292$. (London: The English Universities Press, Ltd., 1959.) 35s. net.

$\mathrm{T}$

HIS is a valuable addition to introductory textbooks on genetics, suitable for undergraduates and for the reader with some knowledge of biology. It covers a wide range, from formal genetics, popula. tion genetics and evolutionary theory to the biochemistry of gene action. It is attractively produced, easy to read and lavishly illustrated with large, clear diagrams which form an integral part of the text.

It is a measure of the rapidity of growth in genetics that the chemical structure of nucleic acids in the chromosomes can now be discussed in an elementary text-book of gonetics, and Dr. Begg is to be congratulated on discussing this and other questions which are not yet fully understood, and making it clear to the reader why they are not understood. This is always exciting and provoking in an introductory book. It is therefore surprising that he should have avoided a fuller discussion of the structure of the genetic unit and the nature of mutation and left the reader high and dry over the interrelationship of deoxyribonucleic acid and ribonucleic acid. It is nowhere made clear that ribonucleic acid is found both in the nucleus and cytoplasm nor that proteins always occur with the deoxyribonucleic acid in the chromosomes. This makes it difficult for the reader to effect a synthesis between the first and last chapters.

There are several misprints which may well lead the beginner astray, for example an extra plus sign has appeered in Fig. 97, and it is to be hoped that the problems posed in the references in the last chapter are not an introduction to the stated problems, with solutions, which follow.

It is a pity that small points of editing should have been allowed to mar an otherwise useful book, a book in which a great deal of effort has been made to use genetic examples from man and to emphasize that geneties is of interest to us all.

Wirma George

\section{IDENTIFICATION OF BLOOD- GROUP ANTIGENS}

\section{The Anti-Globulin (Coombs) Test in Laboratory Practice}

By Dr. I. Dunsford and Jean Grant. Pp. xiii +120 . (Edinburgh and London: Oliver and Boyd, Ltd., 1959.) 12s. $6 d$. net.

T

HE antiglobulin test of Coombs introduced in 1945 was, in fact, a rediscovery, for so long ago as 1908 its principles were worked out by C. Moreschi, an Italian. Dr. Coombs was unaware of this when he introduced his test, but later he duly acknowledged Moreschi's work. The test, as devised by Coombs, Mourant and Race in 1945, is now very extensively used both in routine investigations and in research work.

Many important and substantial advances in blood group serology, that is, the identification of bloodgroup antigens in the cells, and isoantibodies in the serum (or plasma), would not have been possible without the Coombs antiglobulin test. In selecting blood for transfusion the Coombs test is quite the most reliable compatibility test thus far devised. This test has also proved to be extremely useful as a research instrument and, in particular, has proved invaluable in affording us a better understanding of hæmolytic anæmias. This book, written by two experienced workers, reflects the experience generally not only of the Oxford and Sheffield regional transfusion laboratories but, also, that of other transfusion laboratories. It gives an informative account of the Coombs test, the preparation of antiglobulin sera, the applications of the test, and there is a comprehensive list of references for those who wish to read further on the subject. Certainly this book will be very useful to every pathologist and technician who operates a blood bank.

A suitable account of antigens and antibodies is given, their detection by the Coombs test, and the serological basis of this test. The production, processing, and standardization of anti-human-globulin sera, the behaviour of such sera in tests, the technique and applications of the Coombs test, and the various snags which may arise, are all competently dealt with. The authors point out that antiglobulin sera prepared by heating or by dilution may be adversely affected in that they may be suitable only for detection of $\gamma$-globulin coatings. The application of Coombs's test in fields other than blood-group serology, for example in bacteriology, forensic medicine, hæmolytic disease in animals, etc., are briefly but adequately dealt with. This is a useful little book, being compact and concise, and it is to be hoped it will be kept so in future editions which will surely be required.

R. DRumMond

\section{EVOLUTION OF MODERN EDUCATION}

Studies in the History of Education 1780-1870

By Brian Simon. Pp. $375+24$ plates. (London: Lawrence and Wishart, 1960.) 37s. 6d. net.

T HE history of education often lends itself well to a Marxist analysis, and in the case of Mr. Simon's book it has undoubtedly helped to throw fresh light on British social developments in the nineteenth century. What makes this approach exasperating as well as rewarding is its tendency to straight-jacket the material, thereby first illuminating it and then obscuring it-the former by catching it in a sharp focus, the latter by distorting it to fit into a partial pattern of vision.

During 1780-1870 there was indisputably a vast social change, in relationship to which educational principle and practice stood as both cause and effect. Political and economic power shifted from the landowning aristocracy to the Whig magnates and then, in step with technological invention, to an increasingly prosperous middle-class. This was reflected first in the attack of the Philosophical Radicals on the former establishment in Church and State up to 1832 , and secondly in the building up of social institutions in favour of the liberal interest after that date and against the extension of full human rights as yet to the rest of the populace. A trifle tedious in connexion with the first of these phenomena, Mr. Simon's writing seems to catch fire as in Chapters 4 and 5 he describes 